Article

\title{
Restoration of a Historic Building in Order to Improve Energy Efficiency and Energy Saving-Case Study-The Dining Room within the Žiča Monastery Property
}

\author{
Nenad Šekularac ${ }^{1}$, Jelena Ivanović-Šekularac ${ }^{1, *}$, Aleksandar Petrovski ${ }^{2}$, Nikola Macut $^{1}$ \\ and Milan Radojević ${ }^{1}$ \\ 1 Department of Architectural Technologies, University of Belgrade-Faculty of Architecture, \\ Bulevar Kralja Aleksandra 73/II, 11000 Belgrade, Serbia; nenad.sekularac@arh.bg.ac.rs (N.Š.); \\ nikola.macut@arh.bg.ac.rs (N.M.); milan@arh.bg.ac.rs (M.R.) \\ 2 Faculty of Architecture, Ss. Cyril and Methodius University, Boulevard Partizanski odredi 24, \\ 1000 Skopje, Macedonia; petrovski.aleksandar@arh.ukim.edu.mk \\ * Correspondence: jelenais@arh.bg.ac.rs; Tel.: +381-64-11-65-036
}

Received: 28 June 2020; Accepted: 30 July 2020; Published: 4 August 2020

check for updates

\begin{abstract}
A proper systematic approach to the restoration of historic buildings is crucial in the preservation of heritage buildings. This paper presents the unity between the restoration of a historic building and sustainability. The aim of the research is to establish an effective method for the restoration of historic buildings and their reuse and sustainable renovation in terms of energy efficiency, in accordance with modern needs and conservation requirements while maintaining the authentic appearance. The main method in the paper is the observation of a historic building during its restoration and exploitation, analysis and evaluation of the results achieved in improving energy efficiency and energy saving in the example of the building within the Žica Monastery in Serbia, a cultural monument of exceptional importance. The subject of the research is the Dining Room within the Žiča Monastery and the analysis of the restoration results in order to ensure energy refurbishment and cultural heritage enhancement. The research findings are recommendations for the restoration and adaptive re-use of historic buildings, in accordance with modern requirements for comfort and environmental protection. The greatest contribution of this paper is the practical verification of energy refurbishment of the restored historic building, the Dining Room, by applying the principles and measures of energy efficiency, maintaining the authentic appearance of the building, in accordance with the conservation requirements.
\end{abstract}

Keywords: heritage conservation; energy refurbishment of historic buildings; cultural heritage; conservation requirements; sustainability

\section{Introduction and Premises}

Cultural Heritage is more than just a petrified memory of the past that has a particular significance in the life of the nation, it is also an active resource for the future. Reusing and valorizing it changes the way we think about preservation. Since many of the listed buildings have outstanding landscape or picturesque values, it is essential that nothing is carried out that might impair these qualities. Although precious cultural heritage resources are reusable, they are neither renewable nor replaceable. This means that all interventions to modify buildings must involve minimal disturbance to both the buildings themselves and to their wider context [1]. 
Historic buildings and their remains, which belong to the monumental heritage of a society, should be protected from further deterioration, restored and adapted to modern requirements and modern social changes. The restoration of historic buildings that includes energy refurbishment measures while maintaining the authentic appearance and materialization of the building, will ensure successful reuse of the restored building. The subject of this research is the restoration of the Dining Room within the Žiča Monastery property, in the village of Žiča, near Kraljevo, the town in Serbia, in terms of energy efficiency and modern conservation requirements.

Heritage buildings are architectural and historical monuments, and their preservation is crucial in terms of passing on the cultural identity to the future generations [2]. What characterizes this Dining Room is its unchanged role and function in the development of monastic life in the last ninety years.

Architectural heritage and historic buildings are primarily influenced by the bioclimatic design principles, specific resilient architectural structure and strategic design choice of durable construction materials, as well as by characteristic free land space and greenery they are surrounded with. Their sustainability is verified by their endurance and durability measured by hundreds and thousands of years [3,4]. All the construction materials and any planned interventions should be in harmony with the authentic appearance and integrity of the building. The building should meet the space requirements of the new functions [5].

Historic buildings, declared cultural assets, do not differ in the concept of energy renovation from buildings that are not listed. The approach to this type of renewal is based on the needs and specifics of the cultural heritage. Before the restoration and implementation of energy refurbishment measures, the existing characteristics of the historic building, in terms of energy efficiency, should be assessed. Measures to improve energy efficiency in historic buildings not only lead to energy savings but also protect the material historical values and their characteristics [4]. The key to the successful energy refurbishment of historic buildings is to identify and understand existing energy efficient aspects of historic construction, in order to retain and preserve them and have further efficient implementation along with new measures aimed to improve energy efficiency.

Energy retrofit is commonly measured in terms of annual energy savings compared to the building as-is. Not only is energy retrofit of historic buildings undertaken to reduce energy consumption, but also to preserve these buildings for future generations [6].

Scientific literature presents several aspects of the research on environmental evaluation in relation to preventive conservation and thermal comfort, pointing out a balance with the requirements of preservation and enhancement of heritage. However, there are no energy assessment schemes specific to historic buildings $[7,8]$.

EU Energy Efficiency Directives refer to energy consumption reduction and energy savings in existing buildings and do not clearly relate this to historical buildings. Moreover, there is no international act in the field of architectural heritage conservation that deals with their energy refurbishment. European laws do not specify the minimum level of energy performance required for historic buildings. This is a key starting point, as historic buildings are heterogeneous and have different levels of protection and, at this time, regulations do not provide a general recommendation on how to manage energy improvement issues of historic buildings [9].

This European Standard provides guidelines for sustainably improving the energy performance of historic buildings, e.g., historically, architecturally or culturally valuable buildings, while respecting their heritage significance. Not only does this standard apply to historically and architecturally significant heritage buildings, it also applies to historic buildings of all types and ages. This European Standard is used in order to select appropriate measures to improve energy performance, based on an investigation, analysis and documentation of the building including its heritage significance. The procedure evaluates the effectiveness and impact of those measures in relation to preserving the character-defining elements of the building [10].

There are individual examples of regulations enacted at the national level on the treatment of historic buildings. Each country can adopt its own Guidelines for Energy Efficiency Standards in 
Buildings, which will prescribe whether it will comply with the energy efficiency requirements in both existing and listed facilities. In order to cover the gap between architectural heritage and energy refurbishment, the National Cultural Heritage Institutions should launch initiatives that can contribute to solving the problem of energy efficiency of historic buildings in a more efficient way [11].

Considering that the building that is the subject of this study is located on the territory of the Republic of Serbia, the energy efficiency was tested on the basis of the rules currently in force, and the Regulations on Energy Efficiency on Buildings were applied [12]. The Regulations on Energy Efficiency of Buildings adopted in 2011 introduced mandatory energy certification of buildings, and imposed significantly lower permitted thermal transmittance values. According to the Regulations on conditions, content and procedures for issuing certificates on energy performance of buildings, buildings that are under a certain protection regime where the fulfillment of energy efficiency requirements would be conflicting with the protection conditions, are not subject to energy certification [13].

In addition to being used to study the hygrothermal performance of new buildings during preliminary design steps, building dynamic simulation tools are also used to investigate possible strategies for historic building conservation and energy retrofit solutions. However, among the main obstacles for designers is the lack of reliable thermophysical input data for various envelope components as well as intrinsic limitations in the simulation models, especially in relation to geometric features and peculiarities of the heritage buildings. This paper attempts to bridge this knowledge gap, providing critical factors and possible solutions to support hygrothermal simulations of historical buildings [14].

The energy efficiency measures should be carefully planned and implemented in historic buildings, without negatively impacting the historic integrity and character of the building. Continuous observation of buildings after the restoration can reveal possible changes and defects and prevent irreparable damage to historic structures. This, along with regular maintenance, ensures long-term preservation of our historic built environment and sustainable use of our resources [4].

In order to achieve a quality and optimally energy efficient architectural object during its restoration and rehabilitation, it is necessary to:

- Perform on-site observation and analysis of the location, orientation and shape of the building;

- Apply local construction materials wherever possible as authentically applied materials in restoration;

- Improve the thermal insulation of the building envelope in order to avoid thermal bridging;

- Take advantage of favorable insolation and solar heat gains, and provide protection from excessive solar exposure, if possible;

- As for further exploitation, apply an energy efficient heating system in combination with renewable energy sources if possible;

- Use the possibility of natural ventilation of the building.

When it comes to historic buildings, this cannot be consistently applied due to the preservation of the authentic visual appearance. Thermal insulation over the exterior walls should be avoided, since the loss of visual historic environment is incomparable in its significance to slight energy saving. In this way, both the visual appearance of the building and a valuable construction system are protected [4].

Heating and cooling of architectural buildings without adequate thermal insulation requires a larger amount of energy, which means higher operating and maintaining costs The existence of cold perimeter structures on the building, walls and ceilings; the absence of thermal insulation on these surfaces; or the existence of insufficient thermal insulation, leads to: increased heat loss during the winter months, damage caused by condensation within the structural elements as well as space overheating during the summer [15]. Among the harmful effect of condensation is the occurrence of structural damage, which affects the durability of the structure itself and the building as a whole. Condensation is also responsible for the appearance of mold and allergens, which adversely affect human health and create an unhealthy space for living and working. 
The constant visits of believers and guests increase the value of this facility by contributing to tourist visits and religious and cultural tourism. It is not enough to ensure the physical survival of heritage objects; they should also be economically viable [5]. Successful energy refurbishment of historic buildings must identify existing energy aspects of historical construction, in order to properly preserve and effectively implement them along with new measures to improve energy efficiency.

Authenticity is a central concern and an essential criterion of most conservation principles, and preserving authenticity is the highest goal of conservation. Understanding the concept of authenticity (The Nara Document on Authenticity) [16] is of fundamental importance in the research of cultural heritage, in the planning of conservation interventions, as well as in the inscription on the World Cultural Heritage List. Authenticity was defined by The 1994 Nara Document on Authenticity [16]. By preserving the building as an authentic cultural monument, its original function, or by introducing a new one, by improving the comfort conditions in the building that is the subject of restoration and reducing energy consumption, we strive to establish a model of sustainability. Restoration of historic buildings and sustainability are inextricably linked. When it comes to the preservation of cultural built heritage, retrofitting is to be primarily carried out in the interior of the building, in order to maintain all of its original exterior wall aspects [17].

Planned use of natural resources and protection of cultural monuments are basic preconditions for preserving the resources of sustainable cultural development for future generations. The preservation of cultural heritage implies respect for the principles of authenticity of cultural property, its monumental values and stylistic unity [18]. The use of natural and indigenous materials of stone, brick and wood in historic buildings is a reflection of the local terrain, culture, historical and economic characteristics.

The hypotheses of this paper are:

Hypothesis 1. In accordance with conservation requirements and application of appropriate construction measures and authentic construction materials, it is possible to restore the existing devastated building, keep the existing function and improve comfort conditions, while maintaining the authentic appearance and unity with the protected ambient whole, such as the Žiča Monastery;

Hypothesis 2. Restoration of the existing devastated parts of the building and use of energy refurbishment measures ensure energy saving and energy efficiency of the building in accordance with the preservation of the environment.

The goals of this paper are:

- The use of site conditions for the protection and preservation of the historic building without negatively affecting the environment as well as the management of the site;

- Improving the knowledge on the importance of preserving cultural heritage and historic buildings, their potentials, methods of restoration and use of authentic building materials, in accordance with the conservation requirements;

- The use of construction measures in order to improve energy efficiency in the restoration of historic buildings and contribute to the preservation of the environment of this site;

- On the basis of the obtained results on the application of certain types of materials in the restoration and energy refurbishment of the historic building, form recommendations for their preservation, restoration and adaptive reuse, and make the findings of the research available to the academic community.

\section{Methods}

The following analyses and activities were conducted in this research:

- On-site observation-the subject of preservation was determined on the basis of the analysis and evaluation of historic buildings; 
- The case study as a method of studying the case (as a whole) of the example of restoration and improvement of energy efficiency of the Dining Room within the Žiča Monastery, enabled the realization of scientific knowledge;

- Designing and defining criteria for constructive protection based on a preliminary on-site analysis and choosing the type of work that needs to be undertaken in order to restore a facility that has been permanently used for almost a century;

- Analyses of the building materials used in the construction of the historic building;

- Restoration of the building in accordance with the conservation requirements: retaining the authentic elements of the structure (facade walls, roof structure) as well as the authentic appearance of the building;

- Restoration of the historic building and retention of the original appearance, preserving the visual appearance of facade bricks walls and stone details, as well as the interior aspects, in terms of maintaining the existing frescoes on the interior walls and meeting modern principles and requirements of building physics;

- Case study as a research method used in the restoration and improvement of the energy efficiency of the Dining Room within the Žiča Monastery, by examining three different models that can be verified by applying energy refurbishment measures-all three analyzed models enabled conclusions to be drawn and scientific knowledge to be formed;

- Project preparation for the restoration of a historic building, along with checking the possibility of improving the already restored buildings by applying individual interventions in order to improve energy efficiency and energy saving;

- All interventions on historic buildings, aimed at restoring and improving energy efficiency, are reversible processes and can be done in accordance with the conservation requirements;

- Analysis and evaluation of the achieved results by applying various proposed restoration models for the purpose of energy refurbishment, along with permanent use and preservation of the environment.

\section{The Research and the Results for the Dining Room within the Žiča Monastery}

\subsection{Specific Characteristics of the Žiča Monastery Property}

The Žiča Monastery was built at the beginning of the 13th century, in Serbia, near the present-day town of Kraljevo, in the village of Žiča, after which the monastery was named. The role that the founders, Saint Sava and his brother Stefan Nemanjić, assigned to the Žiča Monastery was to be the center of an independent Serbian church and the temple of the Serbian people. Even today, 800 years after its construction, the Žiča Monastery has an exceptional significance and represents an uninterrupted spiritual mission of the holy place for all Orthodox Serbs.

The central temple in Žiča is the Church of the Holy Dormition, which was built from 1206 to 1221 by the Serbian king Stefan Nemanjić, remembered in history as Stefan Prvovenčani, who was also crowned in this monastery [19]. At the time of construction, this location was a perfect choice in terms of architectural space and elements, worthy of the royal endowments and the then modern trends in the construction of the Byzantine world. Seven Serbian kings were crowned in the Žiča Monastery in the previous eight centuries. The Žiča Monastery is a monastery property that consists of several churches and other buildings built over the centuries.

The Žiča Monastery was declared a cultural monument of exceptional importance in 1979. The monastery property includes a number of buildings: the Church of the Holy Dormition, the Church of St. Sava, the Church of the Nativity of St. John the Baptist, the Church of the Holy Apostles Peter and Paul, the Episcopal Palace, the Dining Room, the mansion for nuns and other facilities [19]. The Žiča Monastery has often been destroyed, burned and devastated over the centuries. Today, the Žiča Monastery is a nunnery and nuns lead a monastic life in it. 
The work on the project of static rehabilitation of certain buildings within the Žiča Monastery is the basis for further research that will be presented in this paper by analyzing the existing condition and simulating a model of energy improvement of one of the historic buildings within the monastery property.

The project of structural rehabilitation of the Church of St. Sava and the Dining Room in the Žiča Monastery includes structural strengthening measures in order to protect the buildings and prevent further decay. The Church of St. Sava is a single-nave vaulted building and dates from the fourth decade of the 20th century. The Dining Room is a ground floor building, located in the southwestern part in relation to the outer narthex of the Church of Holy Dormition. In the extension of the Dining Room, on the east side, there is a closed vestibule (porch), to which the Church of St. Sava continues (Figure 1). The Dining Room was built in 1935 (Figure 2). This facility was meant to be a guest house, i.e., a dining room where guests and believers who visit the monastery can relax and have some juice, coffee, tea or liqueur made by the nuns themselves. This facility is used during the morning and afternoon from 9 a.m. to 5 p.m. and is heated when necessary by underfloor heating via heat pumps. This large building, the Dining Room, consists of a reception area, a kitchenette, intended only for making tea, coffee, serving and washing dishes (glasses and cups). It is not meant for preparing, cooking or serving food. There is also one office and a toilet area. The building was reconstructed during 2008 and 2009, when the underfloor heating system was installed in both this building and in the Church of St. Sava, the building extension of the Dining Room. The Dining Room is located between the church and the other part where the storage room is, which continues to the entrance of the monastery property.

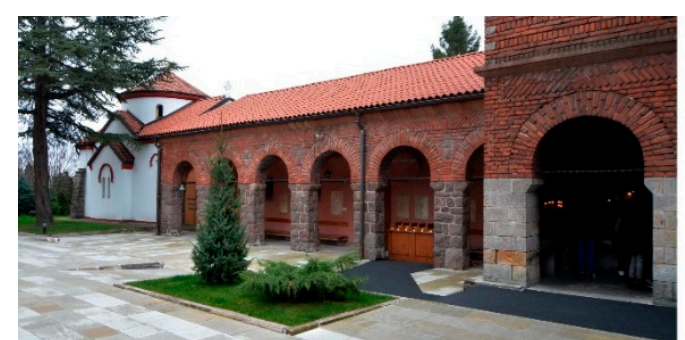

(a)

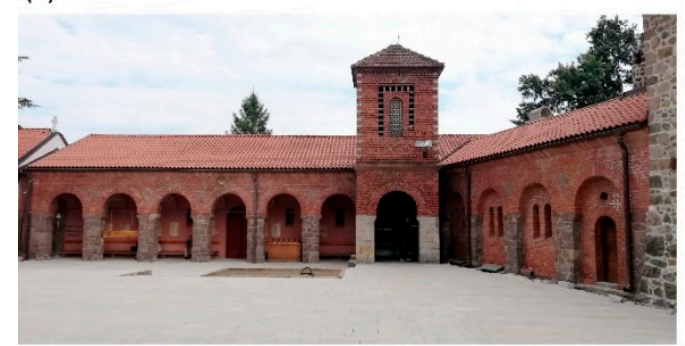

(c)

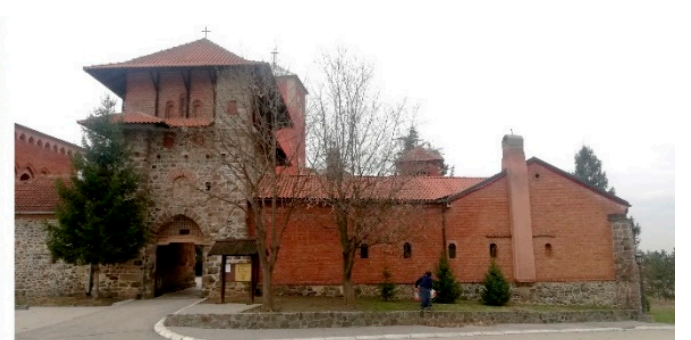

(b)

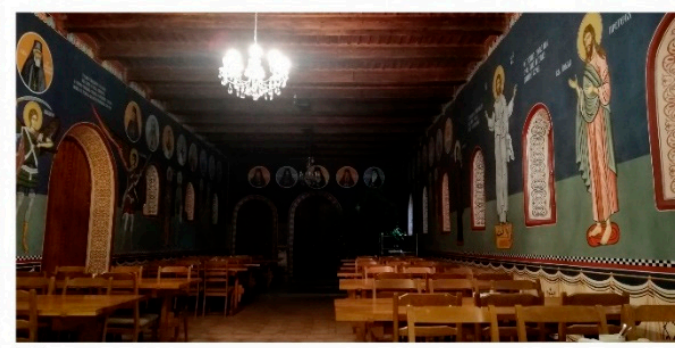

(d)

Figure 1. The Dining Room of the Žiča Monastery property: (a) appearance of the church of St. Sava and the Dining Room from monastery yard, (b) external appearance of the Dining Room and entrance of the monastery property, (c) appearance of the Dining Room from the monastery yard, (d) the interior of the Dining Room (provided photos taken by the author).

Prof. Dr Nenad Šekularac and his associates were hired in 2019 by the representatives of the Žiča Monastery for the design of the structural rehabilitation project for the Church of St. Sava and the Dining Room. Working on this project is the basis for the research that is presented in this paper. It implies analyzing the existing condition and simulating the model of energy improvement of the existing historic building of the Dining Room. 


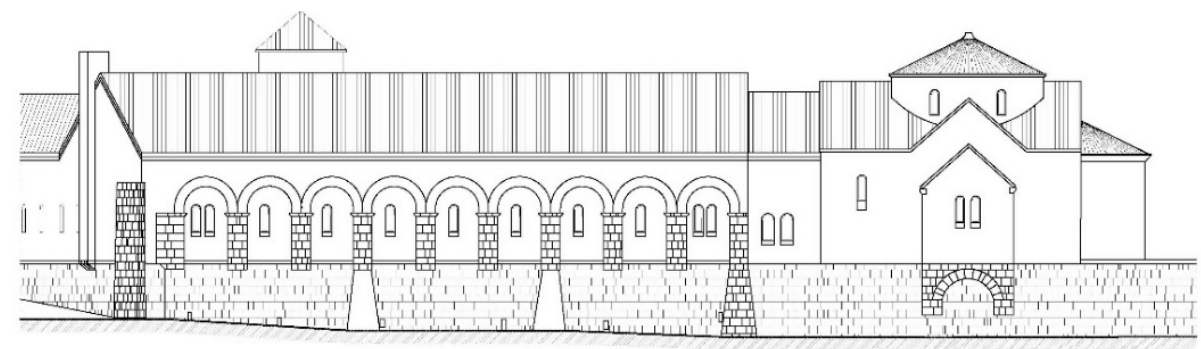

South facade

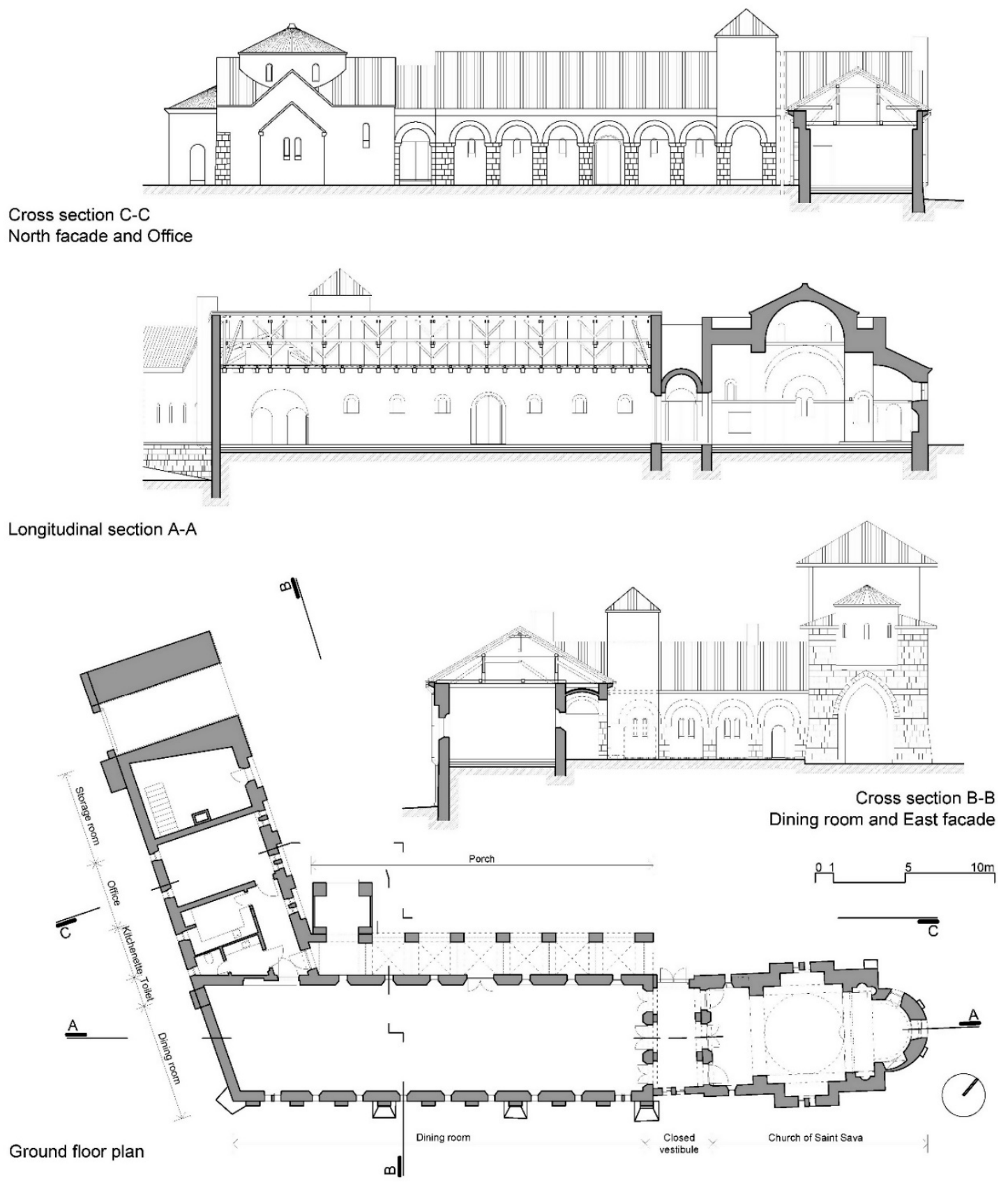

Figure 2. The Dining Room within the Žiča Monastery property. 


\subsection{The Research Findings}

\subsubsection{Energy Efficient Restoration}

Preserving the significant historic qualities of a building undergoing the restoration works, retaining its original function, improving the comfort conditions and reducing energy consumption ensures a model of sustainability. In no way should energy efficiency measures affect the authentic appearance of the heritage building or a protected ambient unit, especially when it comes to a cultural monument of exceptional importance, such as the Žiča Monastery.

Sustainable construction and restoration represent a significant aspect of sustainable development [15] and include:

- Originally used materials and interventions in the restoration process-the use of environmentally friendly building materials that will not negatively affect the site;

- Energy efficiency of buildings;

- Construction and demolition waste management, with the possibility of their future reuse;

This paper deals with the analysis of the groundfloor building of the Dining Room, built in 1935, within the Žiča Monastery property, in terms of its energy efficiency, through the comparison of relevant parameters of three models:

- The first model—the existing condition of the Dining Room (restored in 2008 and 2009)—M01 (Figure 1);

- The second model — the proposal for the 2019 restoration of the Dining Room-M02;

- The third model—the proposal for improving the planned restoration of the 2019 Dining Room -M03.

The two presented restoration models, M02 and M03, were carried out by applying individual construction measures in accordance with the conservation requirements. The energy performance of all these facilities was checked by preparing the Energy Efficiency Study in accordance with the Regulations on Energy Efficiency of Buildings. The proposals for the restoration and improvement of the Dining Room were produced through the application of individual construction measures in accordance with the conservation requirements.

Energy performance simulation for the three models of the Dining Room was performed in the Openstudio, the energy simulation software based on EnergyPlus, energy simulation software [20]. To simulate the model, meteorological data were taken from the EnergyPlus website [21], which displays weather data obtained by the World Meteorological Organization for places, regions and countries in the world.

Definitions of scenarios (models) for complex energy improvement were used for the building performance simulation (BPS) using Openstudio software for the typical meteorological year (TMY) [22]. Building performance simulations (BPS) were performed for the following models of buildings of Trpezarija in the Žiča monastery-existing building model based on the restoration model (MO1) and the two new models (MO2-MO3). Technical advances in BPS (building performance simulation) offer their effective energy efficiency optimization and renewable energy sources (RES) integration. This paper presents the total energy consumption (heating, lighting, electric energy consumption) determined by modeling and simulation. Modeling was carried out by applying a mathematical model for Openstudio software. This supports the dynamical simulation and analysis of building mechanical systems, environmental conditions and energy performance, and it is integrated with EnergyPlus energy simulation software [21].

Verification and analysis of the energy improvement were performed through the simulation and analysis of three different models of restoration of this monastery property through Building Performance Simulation (BPS) methods and energy efficiency optimization. Building Performance Simulation (BPS) is a powerful method and technique for predicting a building's dynamic behavior, 
energy efficiency and renewable energy source (RES) integration optimization. BPS enables a building's environmental technology and sustainability harmonization [21].

The values of parameters and the facility use schedules, adopted for the calculation and simulation of all three models, were shown through the heating system, facility occupancy, lighting and use of electrical appliances, in accordance with the actual needs of facility users established by field observations.

The building is naturally ventilated. The air change rate (ACR) value was set to $1 \mathrm{~h}^{-1}$ for all three models (MO1-MO3) to approximate the ACR in the well refurbished old structure with good air tightness, which has a low value of air infiltration into the object.

\subsubsection{Restoration of the Dining Room within the Žiča Monastery}

The on-sight analysis showed the condition of the mentioned Church of St. Sava and the Dining Room. The current condition of the Dining Room was the first model in the research-M01. The Church of St. Sava was made of bricks with mortar. Its southern wall rests on the perimeter, supporting the stone wall of the monastery property (Figure 1b). In the spring of 2019, during the first in situ analysis, cracks were detected in the walls and vaults of the Church of St. Sava and on the Dining Room building. Structural dampness was also detected in terms of capillary moisture, visible on the lower part of the perimeter walls of both the church and the Dining Room. All these perimeter walls of the Church and the Dining Room are plastered and frescoed on the inside (M01) (Figure 1d). The façade longitudinal wall of the Dining Room, made of façade brick, was erected, like the wall of the church, on the perimeter, supporting the stone wall of the monastery property. On this facade wall of the Dining Room, there are window openings overlooking the surroundings of the monastery property. The Dining Room has its own porch along the entire length of the building facing the monastery yard (Figure 1c). The constructive assembly of the Dining Room consists of longitudinal bearing walls made of bricks and colonnades with columns made of roughly carved squares of gray sandstone (Figure 1c). Brick vaults were made on the porch between the longitudinal wall and the arched structure with columns. Only the façade wall under the porch is plastered and painted (M01). All other perimeter façade walls of the building are made of façade bricks. In continuation of the Dining Room, on the east side, there are three wooden double doors that connect this space to the closed lobby, to which the Church of St. Sava continues. The façade wall of the Dining Room, in the part where the ancillary rooms and the office are located, and towards the monastery yard — the Porte, is also made of brick façade and has sandstone pilasters, which carry an arched brick façade in the upper zone (Figure 1a,c).

Certain cracks are visible in the walls of the Dining Room. Some of these cracks extend from the wreath of the building to the floor. There are also cracks on the porch on the ceiling, on the plastered brick arches. The roof structure is wooden-it is a roof hanger with horns with an extremely large span. Under the heavy load of snow in the winter months, there was an adverse effect on the roof structure, and it transferred those great effects from the load to the wooden ceilings leaning on the longitudinal walls of the building, which caused the appearance of cracks in some places on the walls of the Dining Room. The existing joists were bent due to the heavy load from the roof structure and snow, which led to their deflection and caused the appearance of cracks on the longitudinal walls of the Dining Room. The ceiling is made of planks-paneling, so it is not possible to detect any deformations (M01). The last restoration of the mentioned building and the Church of St. Sava was carried out in 2008 and 2009, when the worn-out roof covering was replaced and underfloor heating was installed in both buildings. The existing floor slab does not have waterproofing, nor do the perimeter load-bearing walls, which causes capillary ascending moisture along the walls. In the church, a final floor covering is a stone floor with marquetry, and granite ceramics (M01) were installed in the entire building of Dining Room. The existing windows of the Dining Room are wooden, single glazed, $4.0 \mathrm{~mm}$ thick glass (thermal transmittance U-values $=5.8 \mathrm{~W} / \mathrm{m}^{2} \mathrm{~K}$ ). The doors of the building, as well as between the Dining Room and the church, are wooden. 
However, in spite of the 2008 and 2009 restoration, moisture remained in the buildings. For this reason, in order to prevent further endangerment of these buildings, the project of a new restoration and structural rehabilitation of the Church of St. Sava and the Dining Room was designed in 2019, which is presented in this paper as a second model-M02.

Works on the protection against capillary rising damp were performed by injecting the perimeter walls of the Dining Room and the Church of St. Sava. These perimeter walls are made of brick. The façade walls of the Dining Room are plastered and frescoed on the inside (M02), and the façade is made of unplastered brick on the outside, except for the wall below the porch. The façade walls around the Church of St. Sava are plastered and frescoed on the inside, and plastered and painted on the outside. Protection of the building from capillary rising damp was necessary in order to protect the stability of the building and prevent further deterioration of the structure, as well as to protect the fresco paintings of all interior walls of both the church and the Dining Room. The restoration implied the removal of the complete floor, along with the underfloor heating system, in the Church of St. Sava and in the Dining Room and the construction of a new floor with waterproofing and a new underfloor heating system (M02).

The restoration project stipulated the construction of a new floor reinforced concrete slab over a layer of lean concrete. The waterproofing layer was above the slab, which was protected on the upper side with a cement screed. A thermal insulation layer (for the installation of heating hoses) was placed over the protective screed, which was covered with another cement screed, which also represented the base for the installation of granite ceramics as the final floor covering in the Dining Room.

The reconstruction of the roof of the Dining Room included the dismantling of the complete wooden roof and replacement with a new roof construction and a new roof covering with shingles. The execution of these works included the protection of the building from the effects of weather and other external influences and the control of rain penetration in order to prevent potential destruction of the existing fresco paintings on the walls. A new roof frame was to be built directly above the Dining Room-a combination of a double roof hanger above the Dining Room itself, and real roof chairs (roof truss) above the wall that separates the Dining Room space from the porch. The ceiling covering is of the same type as the existing wooden paneling.

A steam dam and a thermal insulation layer between the bars were placed over the boards on the ceiling from the upper side, and then the adjustment was performed and in that way a floor was formed within the attic space (M02). Installing thermal insulation in this place was a reversible process. The roof was covered with shingles. In accordance with the project of restoration, when covering the roof planes, it is necessary to install fittings-air vents, in order to enable ventilation of the attic space. All window openings were retained on the façade in terms of rhythm and shape, thus preserving the authentic visual appearance of the building. The windows were replaced with new wooden ones with a $9.0 \mathrm{~cm}$ frame and double thermal insulation glass $(4+12+4 \mathrm{~mm})$ filled with krypton (thermal transmittance $\mathrm{U}$-values $=1.5 \mathrm{~W} / \mathrm{m}^{2} \mathrm{~K}$ ). The entrance door to the building, as well as the door between the Dining Room and the church lobby, was also replaced with a new one made of solid wood. After the new restoration, this space remained authentic in terms of construction elements as well as its function. The new restoration project maintained the purpose of all the rooms.

The proposal to improve the 2019 restoration of the Dining Room is the third model for simulation-M03. For the needs of the research in this paper, a proposal was made to improve the 2019 restoration project in accordance with the maximum possibilities provided by the restoration with the least possible construction interventions. All the facade walls of the Dining Room that have a facade brick on the outside were completely retained. These walls on the inside were plastered and frescoed so that they remain completely authentic. The facade wall of the Dining Room, which is plastered and frescoed on the inside, and plastered and painted on the outside towards the porch, will be improved by adding thermal insulation on the outside and facade plaster (M03). In accordance with the new restoration project from 2019, in the attic space, over the planned layers of the floor, additional thermal insulation was to be installed and supported so that a new floor was formed in 
the attic space (M03). The wall between the office and the storage room was additionally thermally insulated and plastered on the side of the storage room, i.e., the unheated space, and in this way the improvement of this internal wall was performed (M03).

The improvement included the intervention on the windows and replacement with a new wooden one, with a frame of $11.0 \mathrm{~cm}$ and three-layer thermal insulation glass $(4+8+4+8+4 \mathrm{~mm})$ filled with xenon in order to improve energy efficiency and improve the overall comfort and quality of living in this space (thermal transmittance U-values $1.0 \mathrm{~W} / \mathrm{m}^{2} \mathrm{~K}$ ).

\subsubsection{Energy Performance Analysis}

A comparative review of all three analyzed models of the Dining Room within the Žiča Monastery can determine the extent to which the restoration and proposed energy refurbishment measures affect the reduction in annual energy demands basis (Table 1).

Table 1. Comparative review of the improvement of the building envelope in terms of thermal protection and reduction in annual energy demands, checked through simulation on the Dining Room within the Žiča Monastery.

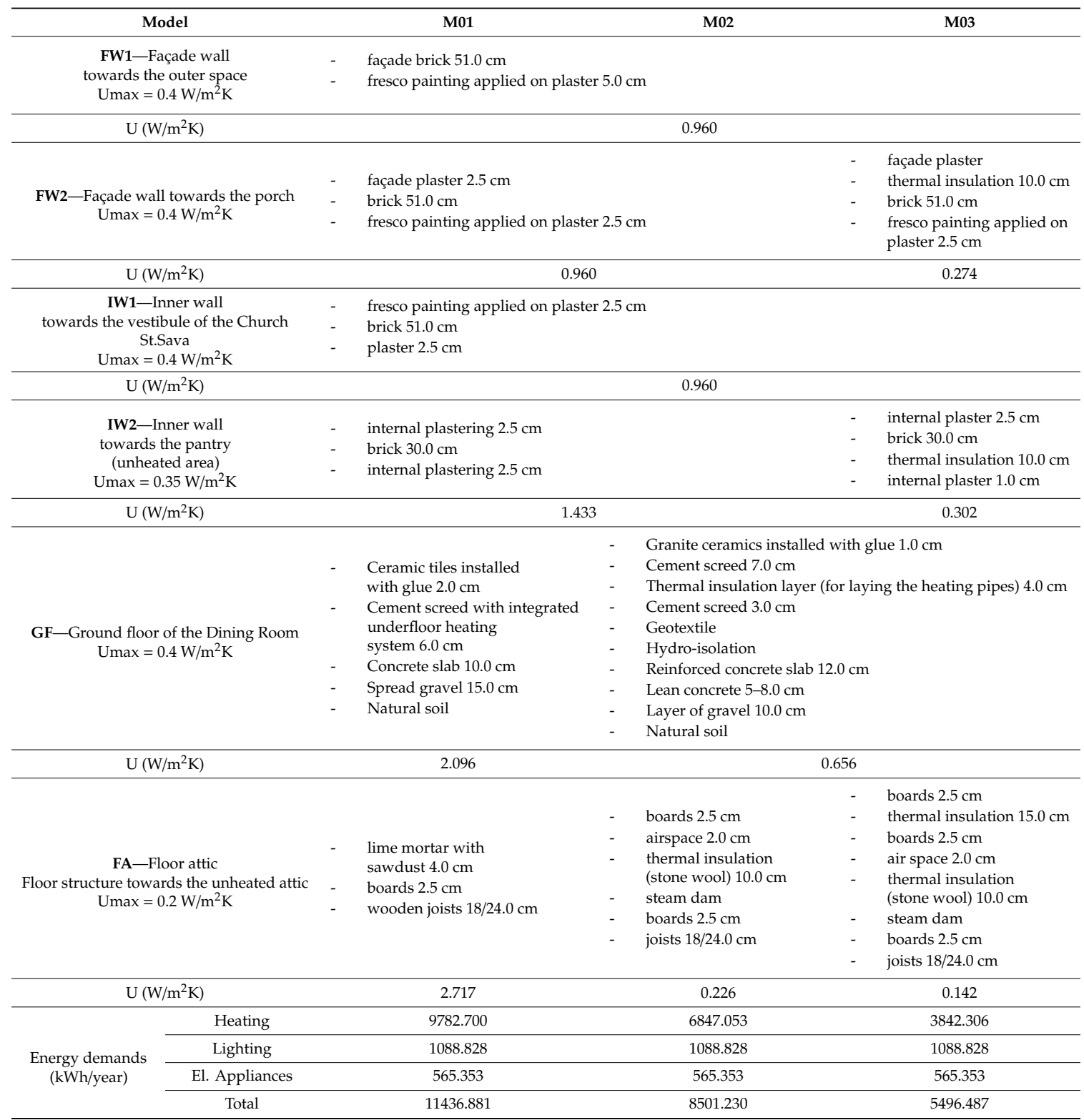


The calculation of the required energy included the analysis of three models of the Dining Room facility (M01-M03), i.e., the simulation of all three models performed on the facility that was the subject of this research in order to check the correctness of the refurbishment approach.

The values of parameters and the way of using the building, which were adopted for the calculation and description of the heating system performance, space occupancy, lighting, use of electrical appliances, were adopted in accordance with the real needs of the building users. The visiting schedule was checked and defined in consultations with the nuns of the monastery. The Dining Room receives visitors in the period from 9 a.m. to 5 p.m. every day of the year. Large tourist groups of up to 50 visitors are allowed to stay for a short time and refresh themselves with tea or coffee in the Dining Room area. In that sense, the frequency of use of light and equipment was obtained in accordance with the common experience and instructions provided by the nuns who live in the monastery, and in relation to working hours and the appropriate way of using this space.

The thermal transmittance (U-value) of the construction elements for all of the three models were calculated according to the harmonized Serbian standard SRPS EN ISO 6946 and the material properties were obtained from the Serbian rulebook of buildings' energy efficiency [23]. The U-values of the proposed energy refurbishment measures are shown in Table 1.

For the simulation of the heating energy demand, the calculated efficiency of the heat pump was $4.02(\mathrm{CoP})$, which delivered hot water at $32{ }^{\circ} \mathrm{C}$ to the radiant floor heating in all of the spaces of the Dining Room considering that the interior conditions and design temperatures for this type of building are not regulated, the interior temperature thermostat for the winter period was set to a common value of $21^{\circ} \mathrm{C}$.

Since the analysis of energy performance did not include the simulation of the cooling system, cooling in the summer months was not considered, because there is no energy consumption for it. The building does not need air conditioning in the summer months, since massive perimeter walls and small facade openings in the form of windows provide a comfortable living space that does not overheat.

The proposed energy efficiency measures (Table 1, Model M02) would reduce the specific annual heating demands by $25.67 \%$ compared to the current condition of the restored facility (Table 1, Model M01). By improving this model with new interventions in order to further improve energy efficiency of the Dining Room (Table 1, Model M03), the specific annual heating demands would be reduced by $51.94 \%$ compared to the current state of the restored building (Table 1, Model M01). If we were to compare a possible improved Model M03 (Table 1) to the Model M02 (Table 1), as proposed by the 2019 restoration, the specific annual heating demands would be reduced by $35.34 \%$.

Considering that the rate of use of the equipment, lights and occupancy are the same, the most indicative aspect is the heating energy demand. The efficiency of the refurbishment measure proposed in the three models are presented in Table 2. From the results of the energy performance simulating presented in Table 1, it can be concluded that the Model M03 significantly outperforms the Model M02 and it is an improvement of the baseline Model M01.

Table 2. Energy performance of the three models of the Dining room.

\begin{tabular}{cccc}
\hline Energy Demand $\left(\mathbf{k W h} / \mathbf{m}^{\mathbf{2}} \mathbf{\text { year}}\right)$ & Model M01 & Model M02 & Model M03 \\
\hline Heating energy demand & 46.72 & 32.70 & 18.35 \\
Lighting & 5.20 & 5.20 & 5.20 \\
Appliances & 2.70 & 2.70 & 2.70 \\
Total energy demand & 54.62 & 40.60 & 26.25 \\
\hline
\end{tabular}

Considering that the rate of use of the equipment, lights and occupancy are the same, the most indicative aspect is the heating energy demand. The efficiency of the refurbishment measure proposed in the three models is shown in Table 2. From the results of the energy performance simulating 
presented in Table 1, it can be concluded that the Model M03 significantly outperforms the Model M02 and it is an improvement of the baseline Model M01.

The energy performance of the three models throughout the year is shown in Figure 3. The peak heating demand was in the December-January period, having the lowest demand in May and September. In the peak demand period, in December, the Model M01 had a heating energy demand of approximately $1700 \mathrm{kWh}$, the Model M02 had $1200 \mathrm{kWh}$ which was a $29.4 \%$ decrease compared to Model M01, while the Model M03 had a heating energy demand slightly above $750 \mathrm{kWh}$, which was approximately 55.8\% less than the baseline Model M01 and 37.5\% less compared to Model M02 for the same period.

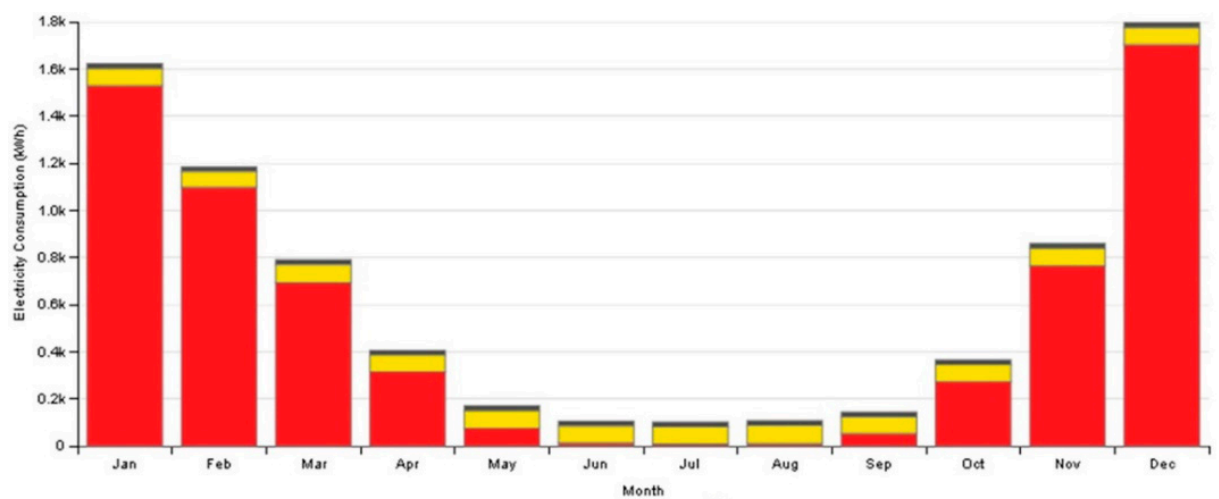

(a) Model M01

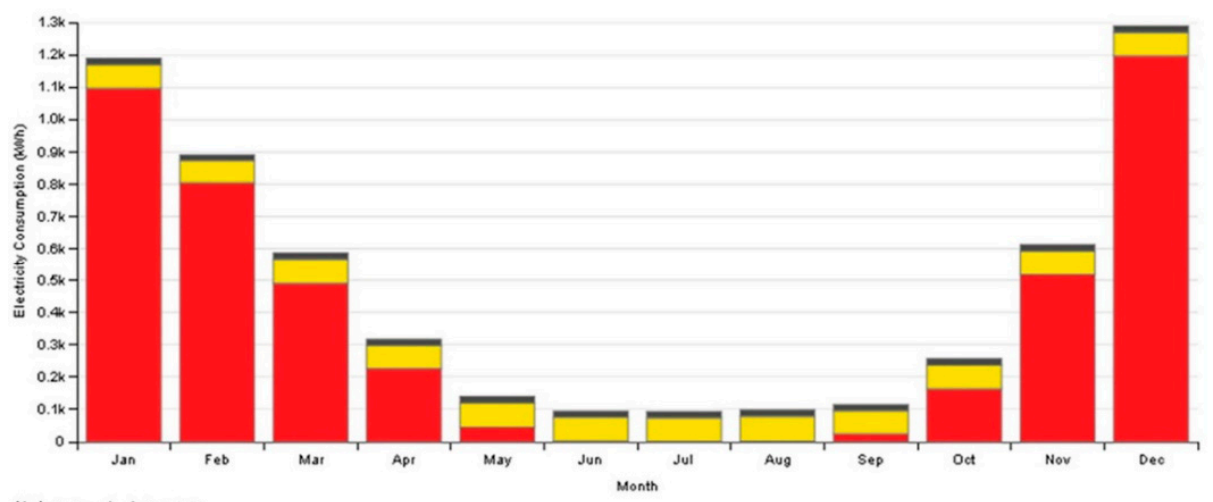

(b) Model M02

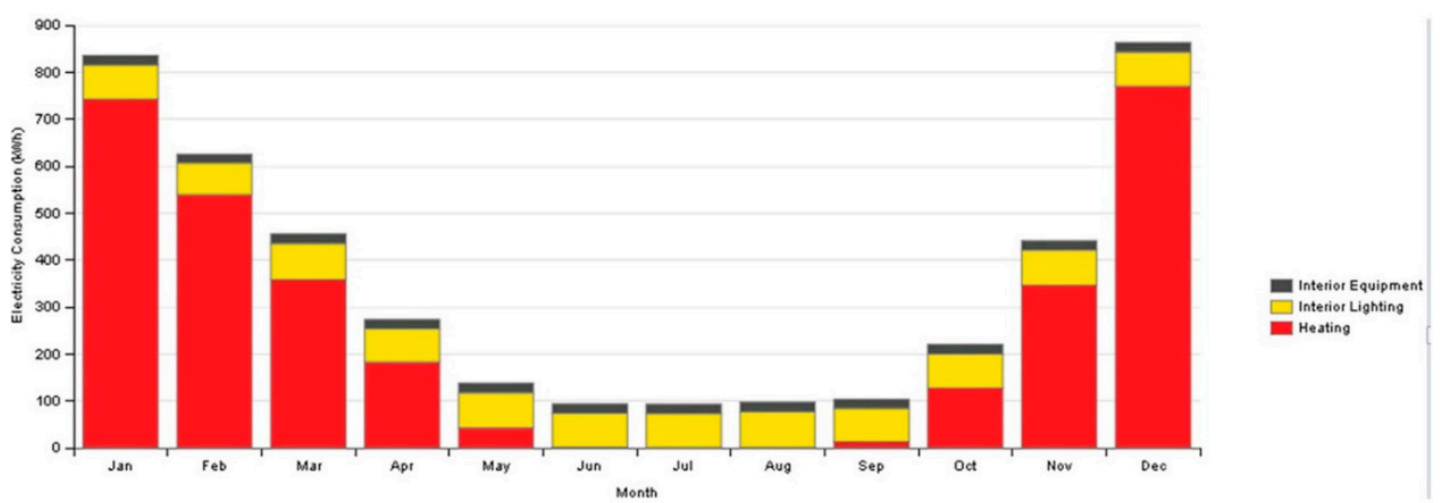

(c) Model M03

Figure 3. Monthly energy consumption of the models. (a). Model M01; (b). Model M02; (c). Model M03. 
From the three models, it is evident that as the heating energy decreased in Model MO3, the interior lighting energy had a larger share in the overall energy demand of the building, despite being the same in all of the three models.

The monthly heating loads in relation to the outdoor temperature variation are shown in Figure 4. It is evident that the heating load in Model M03 was almost twice as low as Model M01 in December and January.
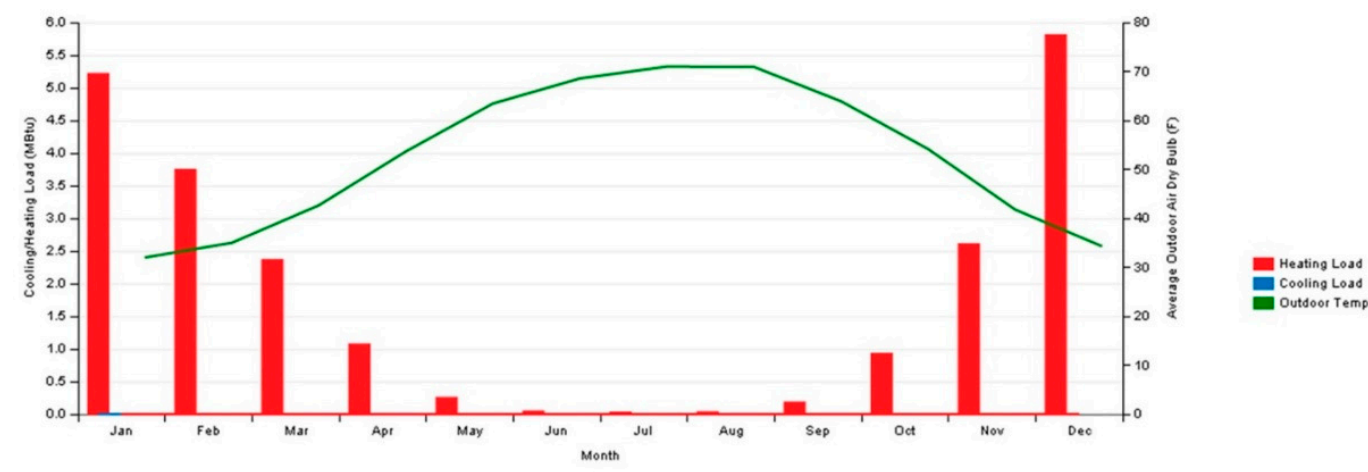

(a) Model M01

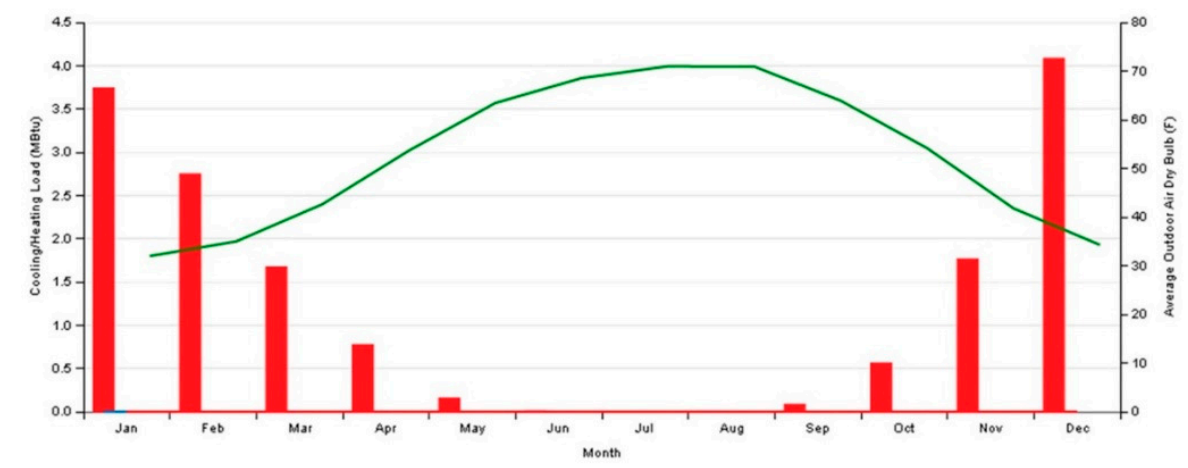

Eesting Loss Goutoor Teme

(b) Model M02

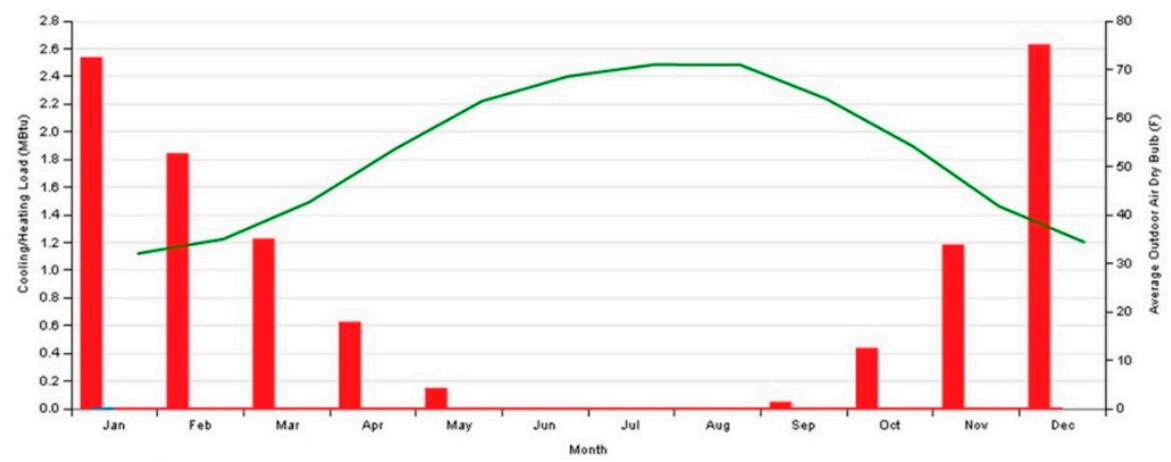

Eesting Losd Goutoor Temp

(c) Model M03

Figure 4. Monthly load profiles. (a). Model M01; (b). Model M02; (c). Model M03.

The influence of the windows on the energy performance of the analyzed models is shown in Figure 5. The solar heat gains and losses were the highest in Model M01 and the lowest in the Model M03, showing the superior energy efficiency performance of the windows used in the latter model. The losses in Model M03 were more than twice as low as the losses in Model M01. 


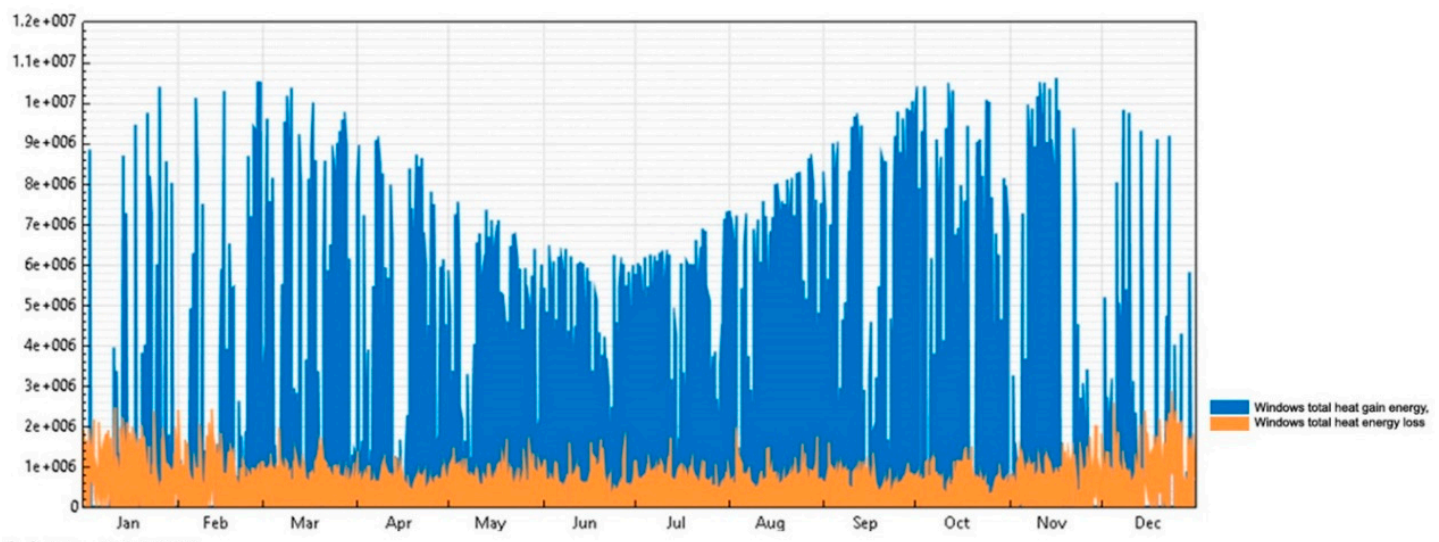

(a) Model M01

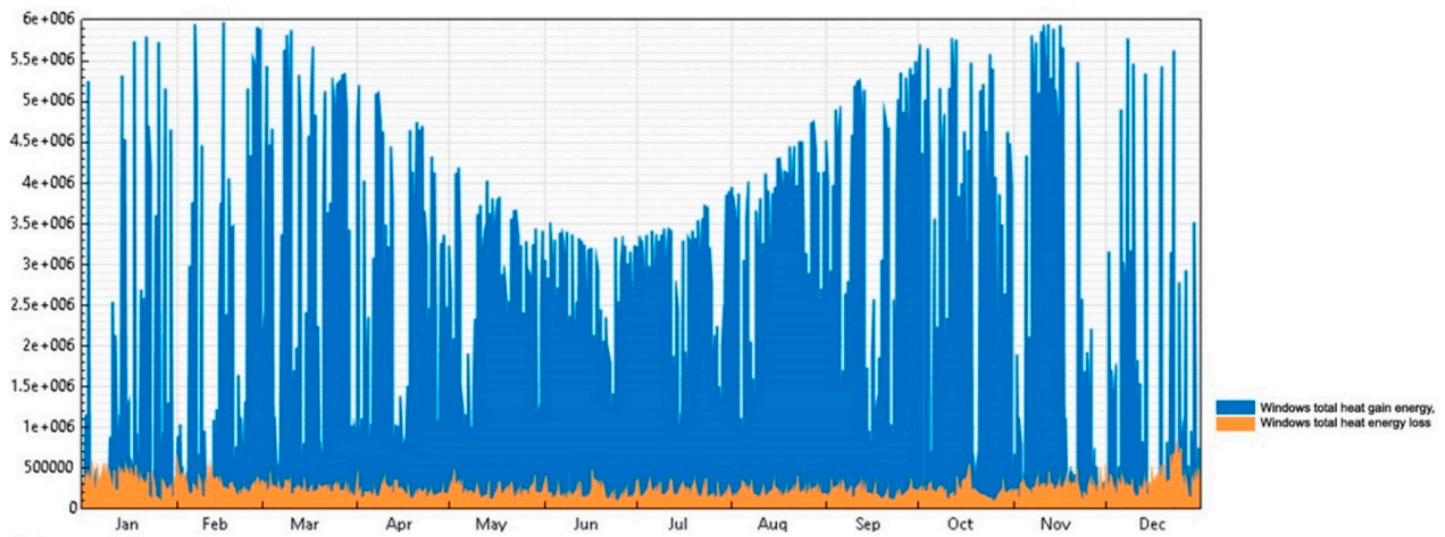

(b) Model M02

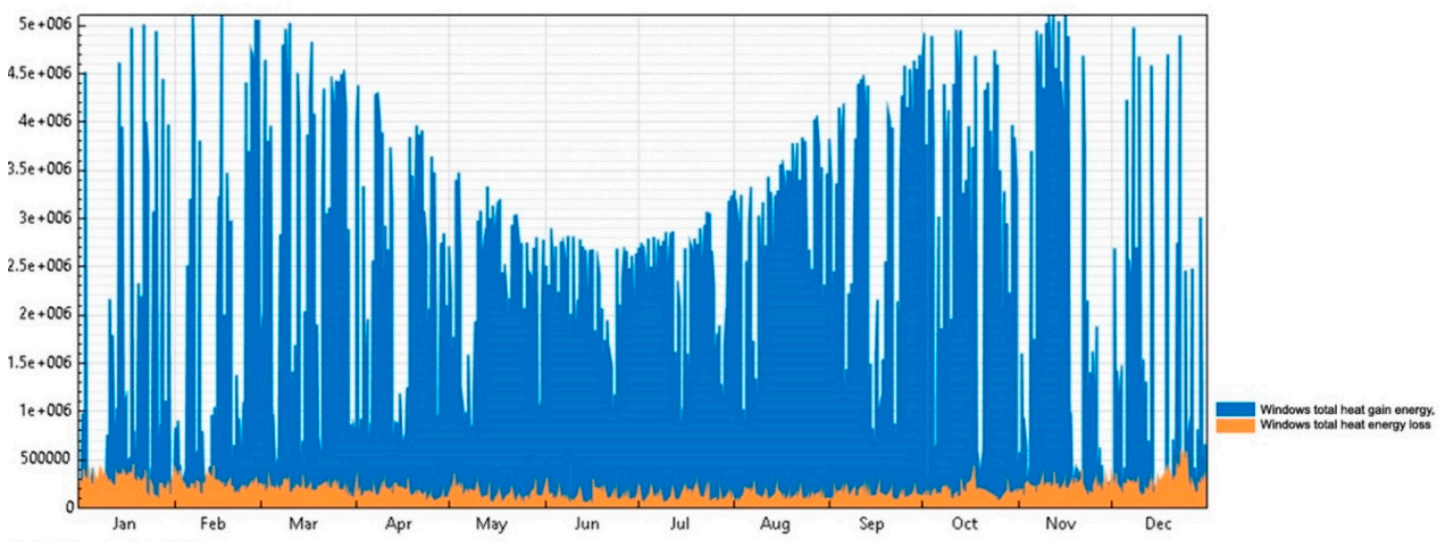

(c) Model M03

Figure 5. Windows heat gain and loss energy. (a). Model M01; (b). Model M02; (c). Model M03.

The interior comfort of the Dining Room building was analyzed in terms of mean radiant temperature, as shown in Figure 6. It can be noted that the temperature variations in Model M01 in each month throughout the year were higher than the other two models. The Model M03 had the lowest temperature variations, where in the winter the lowest temperature was $10^{\circ} \mathrm{C}$, and in the summer the peak was $24^{\circ} \mathrm{C}$, due to the low U-values of its building envelope. For comparison, the minimum and the maximum temperatures in Model M01 were $0-32{ }^{\circ} \mathrm{C}$, while in Model M02, they were $5-32{ }^{\circ} \mathrm{C}$. 


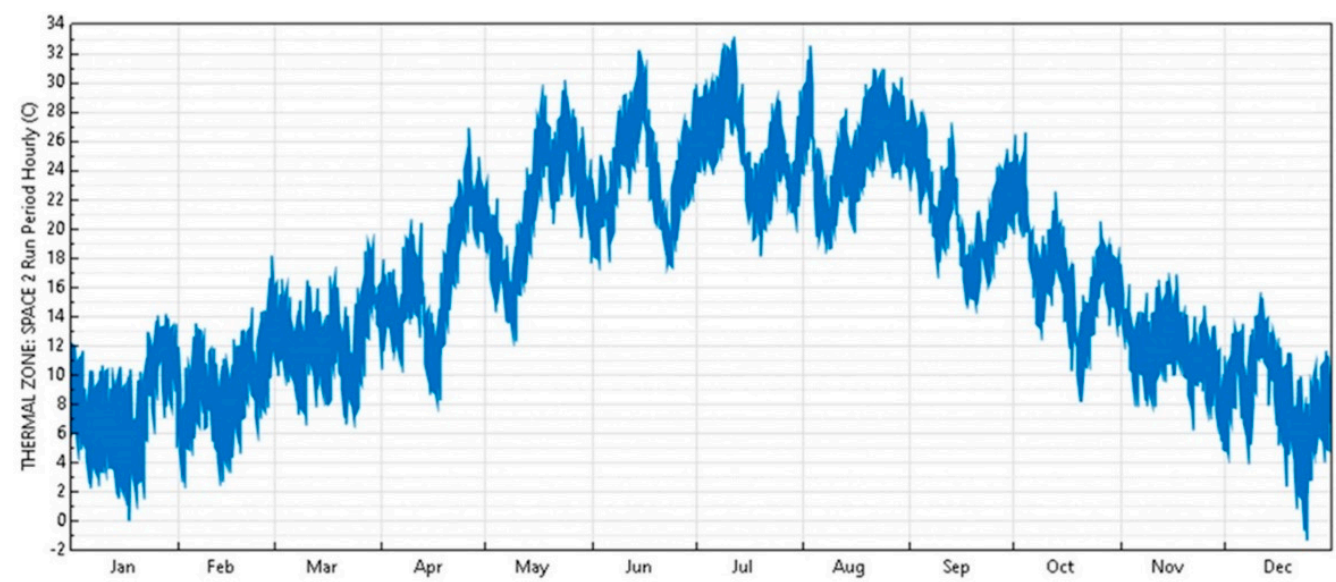

(a) Model M01

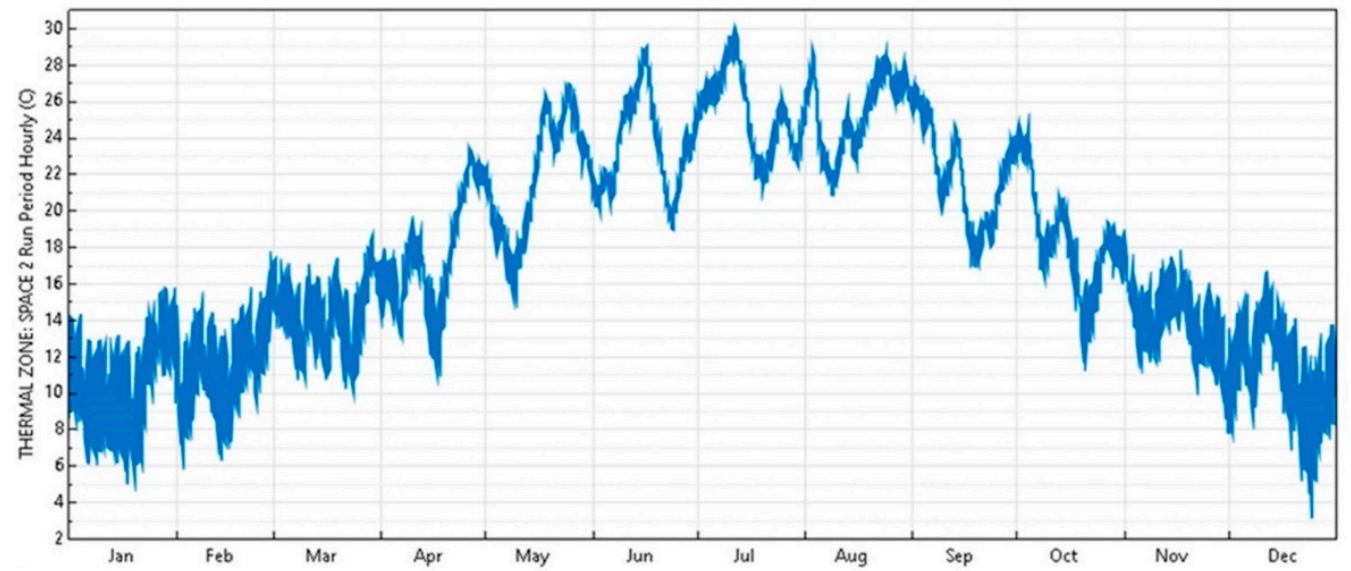

(b) Model M02

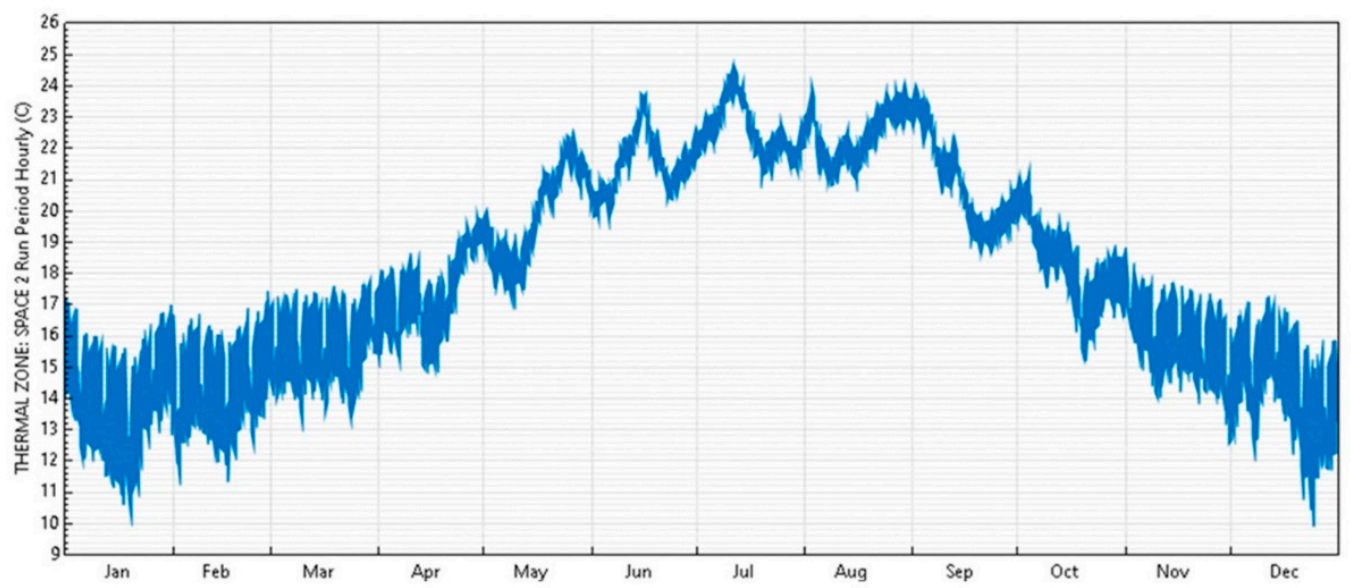

(c) Model M03

Figure 6. Mean radiant temperature. (a). Model M01; (b). Model M02; (c). Model M03.

Furthermore, the air temperature analysis of the three models is shown in Figure 7. The poor thermal characteristics of the building envelope of Model M01 forced the heating system to work harder and spend more energy in the heating season, considering that it had to start from the lowest temperature of $0{ }^{\circ} \mathrm{C}$ in December-January and to achieve a relatively comfortable air temperature of $21^{\circ} \mathrm{C}$. The lowest air temperature in Model M02, for the same period of December-January, was slightly higher amounting to $3{ }^{\circ} \mathrm{C}$, whereas in the Model M03, it was significantly higher, amounting to $7^{\circ} \mathrm{C}$, thus decreasing the starting point of the heating system and leading to lower heating energy consumption for achieving an interior air temperature of $21^{\circ} \mathrm{C}$. 


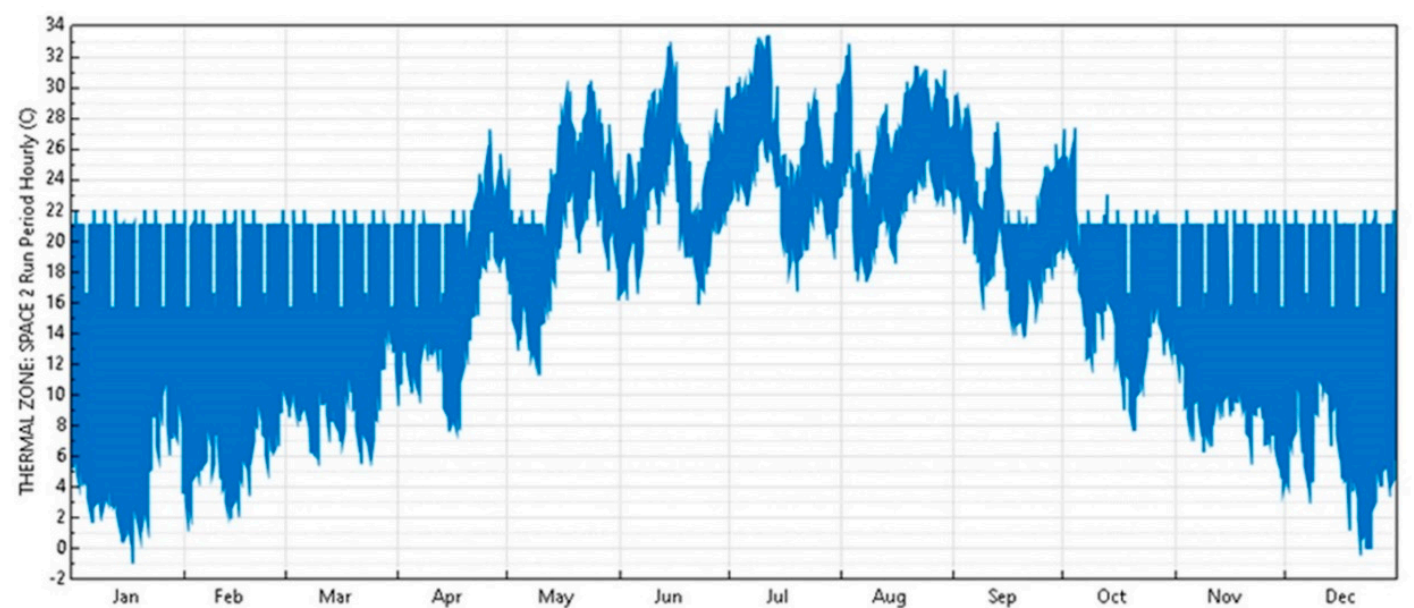

(a) Model M01

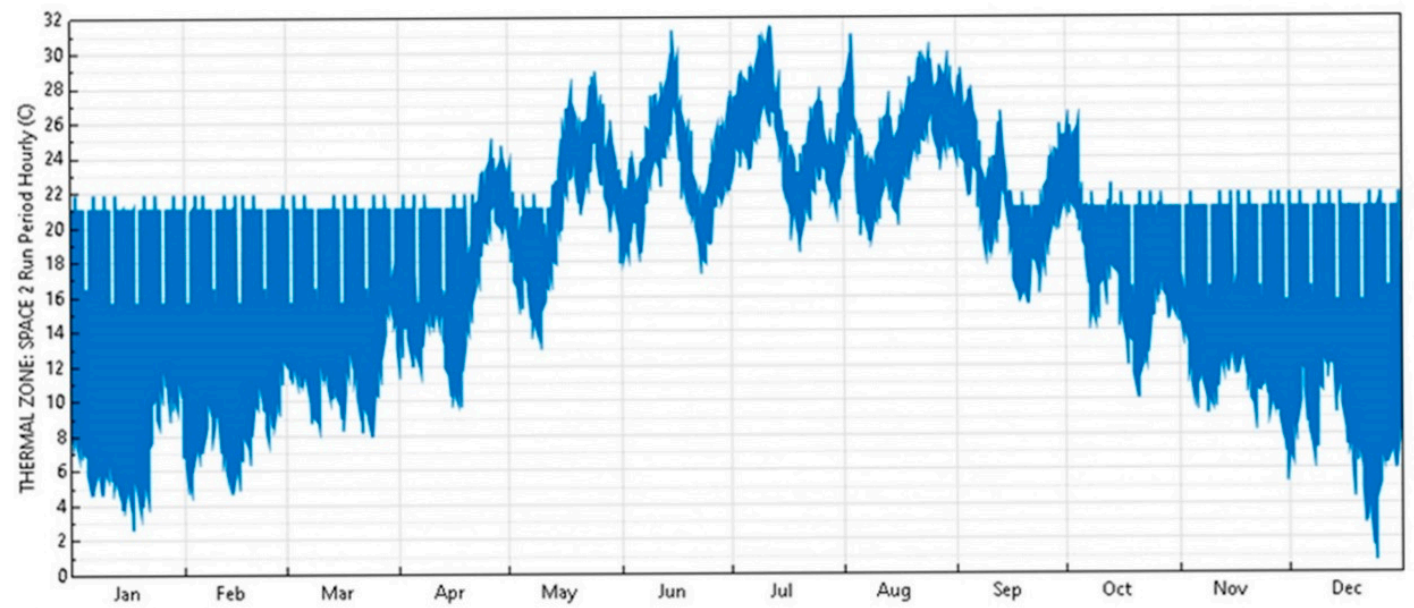

(b) Model M02

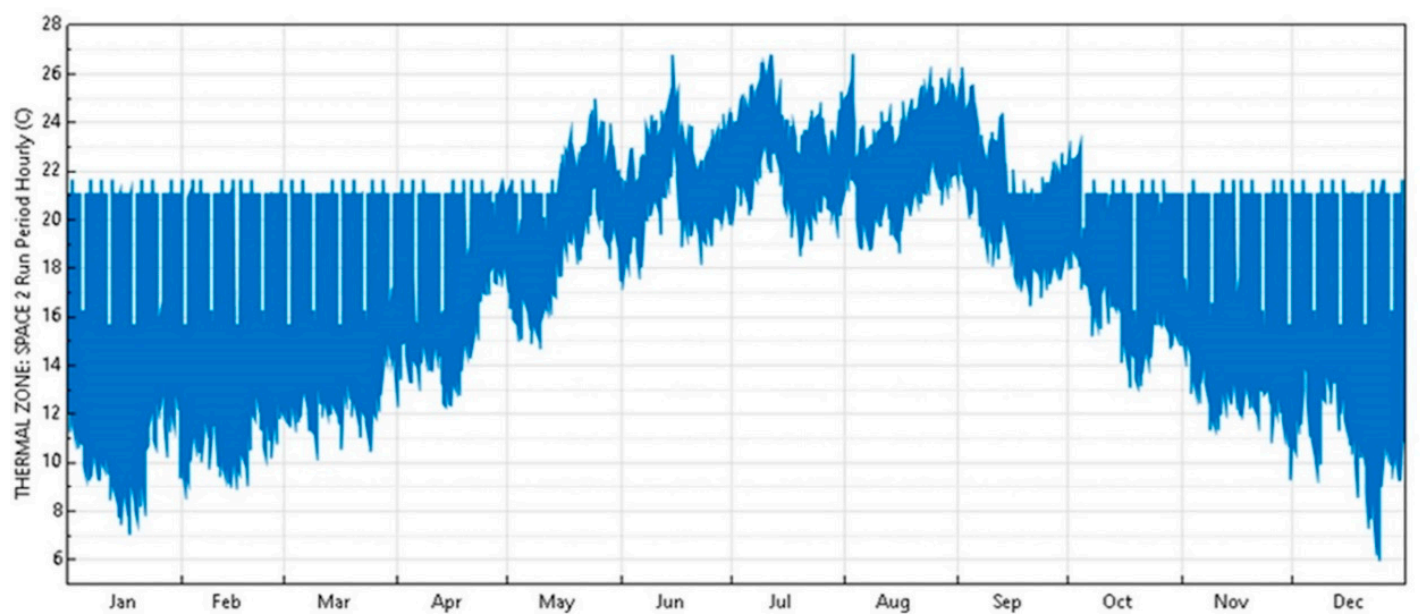

(c) Model M03

Figure 7. Mean air temperature. (a). Model M01; (b). Model M02; (c). Model M03.

\section{Discussion}

The analysis of the Dining Room within the Žiča Monastery, through the simulation of three models and proposed measures of structural rehabilitation and energy refurbishment, leads to the conclusion that it is possible to achieve satisfactory energy saving by applying maximum thermal protection measures on the elements of the building envelope, in accordance with the conservation 
requirements and without negatively impacting the visual character of the building. By analyzing and comparing the obtained values of total heat losses in all three models of the Dining Room building: the building restored in 2008 and 2009, the 2019 restoration project and the proposed improvement to minimize heat loss, data on reducing specific annual heating demands were obtained.

By analyzing and evaluating this historic building through examples of restoration and proposed measures to improve energy efficiency, and the simulation and verification of new models of buildings, the authors presented results that have not been evaluated in this way in literature ever before. The authors of this paper came to know about the realistically obtained values and achieved energy saving results in a specific example of a historic building by applying thermal protection measures in accordance with all conservation and restoration requirements and taking into account the protection of the site.

The hypotheses were tested by field observation, along with the valorization of the building within the Žiča Monastery property and energy efficiency testing for all models (M01-M03) via BPS (Building Performance Simulation). The obtained results confirmed the hypothesis that it is possible to improve comfort conditions and energy efficiency and achieve energy saving by applying appropriate rehabilitation and construction measures in the process of restoration of historic buildings, taking into account conservation requirements and maintaining the authentic appearance of buildings. All these measures are applied in order to maintain the original function of the Dining Room within the Žiča Monastery, a cultural monument of exceptional importance.

This research confirmed the conclusion made by Murgul [24] that the protection of a historic building does not only cover the preservation of visual historic environment, but also involves the protection of the distinctive construction design that is environmentally optimal and centuries old.

This research once again points out how important it is to properly consider all factors that adversely affect the building that is subject to protection and restoration, because the energy efficiency of historic buildings can only be successful without negatively impacting their historic character and integrity, which confirmed the research study carried out by Hensley and Aguilar [25].

This research confirmed the conclusions made by Hensley and Aguilar [25], which relate to the need for regular maintenance of historic buildings, monitoring of restored buildings during their use and the application of long-term protection measures to preserve the historic character and integrity. Additionally, the research confirms the conclusion made by Turanjanin et al. [26] that thermal insulation of the house envelope can reduce heating energy.

This research verified the principles and measures of energy efficiency aimed at achieving energy refurbishment of the building that belongs to the Žiča Monastery property-a declared cultural monument of exceptional importance. This indicates the professional significance and justification of this research from a scientific point of view as well as from the point of view of practical application and possibilities of realization in other localities with historic buildings of similar constructive structure and materialization. The research will be verified directly through practical application at this site (model M02), which is its greatest contribution.

The research findings confirmed the conclusion made by Bionaz [9], which is that ancient builders also thought about the energy performance of buildings and that their knowledge and skills applied to historic buildings were unfairly underestimated, whereas today's attempts to improve buildings to meet the required standards are overestimated.

This research confirmed the conclusion made by Vozikis [27] that the application of the mentioned construction measures and materials in the restoration and energy refurbishment of the historic buildings presented in this Case Study, is a reversible procedure. In this way, the historic building, as an object of protection that is being restored, can be returned to its original condition without any damage. 
Recommendation for Increasing Energy Efficiency and Re-Usability Potential of Historic Buildings in Preservation and Building Restoration Project

Energy efficiency measures for heritage buildings should include the following procedures, in accordance with the conservation requirements:

- Optimal thermal insulation of building envelope;

- Heat loss reduction;

- Heating installation.

Taking into account the historic and architectural character and integrity of heritage buildings, as prescribed by the conservation requirements, it is not permitted to apply standard measures of thermal insulation by installing thermal insulation on the outside of the facade walls.

The proposed energy efficiency measures that were applied in order to achieve energy refurbishment of the historic building of the Dining Room within the Žiča Monastery property are as follows:

- Thermal insulation of the perimeter walls where it is possible and only from the inside, which was the case with only one wall in the unheated storage room, while all the walls in the main space of the Dining Room are facade walls and fresco painted on the inside, and it is not possible to thermally insulate them on the inside;

- Thermal insulation of floors on the ground;

- Thermal insulation of the mezzanine structure (floor structure) towards the unheated attic;

- Replacement of facade joinery (windows and front doors);

- New heating system;

- Energy management.

\section{Conclusions}

The need to preserve the existing historical building and prevent its further decay, while preserving the fresco paintings on the inside of all perimeter walls and authentic brick facade and maintaining the continuity of the original purpose of this building, influenced the restoration of the Dining Room within the Žiča Monastery property. The application of selected construction measures in accordance with conservation requirements, in order to improve the energy efficiency and comfort conditions of the building, enables an uninterrupted connection between cultural heritage and modern needs while maintaining the original purpose and authentic visual appearance of the building.

In order to increase energy efficiency of listed buildings during the restoration project, it is necessary to:

- Use the conditions of the site in order to ensure protection and preservation of the historic building without disturbing the environment;

- Carry out a thorough analysis of the current condition of the building;

- Determine the type and level of restoration;

- Select adequate construction measures in order to improve energy performance and maintain the original function of the space in accordance with conservation requirements;

- Establish energy management at this site and make the correct choice of the method of obtaining total annual energy demands in order to achieve energy saving and energy efficiency, along with environmental protection.

It can be concluded that the design and realization of historic and listed buildings restoration works, and the application of adequate energy efficiency measures, require an individual approach to each cultural monument. In order to save energy and reduce heat losses, it is necessary to install thermal insulation in the building envelope, in accordance with conservation requirements, 
because this is the only way to significantly improve the energy efficiency of the historic building. While respecting the conservation requirements and maintaining the authentic appearance of the Dining Room building within the Žiča Monastery property, various models of restoration of this building were tested and analyzed using the BPS (building performance simulations) method. The main contribution of this paper is the possibility of practical verification of the achieved results of energy refurbishment by applying the principles and measures of energy efficiency in the restoration of the listed historic building.

Author Contributions: All authors contributed equally to this paper. Conceptualization and methodology, N.̌̌., J.I.-̌̌s., N.M. and A.P.; validation, investigation, N.Š., J.I.-Š., A.P., N.M. and M.R.; writing—original draft preparation: N.Š., J.I.-Š., A.P., N.M. and M.R.; writing-review and editing N.Š., J.I.-Š., A.P., N.M. and M.R. All authors have read and approved the final manuscript.

Funding: This paper was written as a part of the project "Spatial, Environmental, Energy and Social Aspects of Development of Settlements and Climate Change", under the Grant number (TR 36035) financed by the Ministry of Education and Science of the Republic of Serbia for the period 2011-2020.

Conflicts of Interest: The authors declare no conflict of interest.

\section{References}

1. Franco, G.; Magrini, A. Historical Buildings and Energy; Springer International Publishing AG: Basel, Switzerland, 2017.

2. Mısırlısoy, D.; Günçe, K. Adaptive reuse strategies for heritage buildings: A holistic approach. Sustain. Cities Soc. 2016, 26, 91-98.

3. Todorović, M.; Ećim-Đurić, O.; Nikolić, S.; Ristić, S.; Polić-Radovanović, S. Historic building's holistic and sustainable deep energy refurbishment via BPS, energy efficiency and renewable energy-A case study. Energy Build. 2015, 95, 130-137. [CrossRef]

4. Šekularac, N.; Šumarac, D.M.; Čikić-Tovarović, J.L.; Čokić, M.M.; Ivanović-Šekularac, J.A. Re-use of Historic Buildings and Energy Refurbishment Analysis via Building Performance Simulation: A Case Study. Therm. Sci. 2018, 22, 2335-2354. [CrossRef]

5. Günçe, K.; Misırlısoy, D. Assessment of Adaptive Reuse Practices through User Experiences: Traditional Houses in the Walled City of Nicosia. Sustainability 2019, 11, 540. [CrossRef]

6. Webb, A.L. Energy retrofits in historic and traditional buildings: A review of problems and methods. Renew. Sustain. Energy Rev. 2017, 77, 748-759. [CrossRef]

7. Lucchi, E. Multidisciplinary risk-based analysis for supporting the decision making process on conservation, energy efficiency, and human comfort in museum buildings. J. Cult. Heritage 2016, 22, 1079-1089. [CrossRef]

8. Muñoz-González, C.M.; Leon-Rodriguez, A.L.; Medina, R.C.S.; Teeling, C. Hygrothermal Performance of Worship Spaces: Preservation, Comfort, and Energy Consumption. Sustainability 2018, 10, 3838. [CrossRef]

9. Bionaz, C. Preservation and energy behavior in Aosta Valley's traditional buildings. In Proceedings of the VerSus 2014-International Conference on Vernacular Heritage, Sustainability and Earthen Architecture, Valencia, Spain, 11-13 September 2014; pp. 129-134.

10. Energy efficiency guidelines on historic buildings. In Conservation of Cultural Heritage. Guidelines for Improving the Energy Performance of Historic Buildings; European Committee for Standardization (CEN), 2017.

11. Mazzarella, L. Energy retrofit of historic and existing buildings. The legislative and regulatory point of view. Energy Build. 2015, 95, 23-31. [CrossRef]

12. Srbija, R. Ministarstvo životne sredine, rudarstva i prostornog planiranja (Minister of Environment, Mining and Spatial Planning), Pravilnik o energetskoj efikasnosti zgrada (Regulations on Energy Efficiency of Buildings-Rulebook on energy efficiency of buildings); Official Gazette of the Republic of Serbia: Belgrade, Serbia, 2011.

13. Srbija, R. Ministarstvo životne sredine, rudarstva i prostornog planiranja (Minister of Environment, Mining and Spatial Planning), Pravilnik o uslovima, sadržini i načinu izdavanja sertifikata o energetskim svojstvima zgrada (Regulations on Conditions, Contents, and Methods of Certificate Issuance regarding energy efficiency of buildings); Official Gazette of the Republic of Serbia: Belgrade, Serbia, 2012. 
14. Akkurt, G.G.; Aste, N.; Borderon, J.; Buda, A.; Calzolari, M.; Chung, D.; Costanzo, V.; Del Pero, C.; Evola, G.; Huerto-Cardenas, H.; et al. Dynamic thermal and hygrometric simulation of historical buildings: Critical factors and possible solutions. Renew. Sustain. Energy Rev. 2020, 118(C), 109509. [CrossRef]

15. Šekularac, N.; Ristić, N.D.; Mijović, D.; Cvetković, V.; Barišić, S.; Ivanović-Šekularac, J. The Use of Natural Stone as an Authentic Building Material for the Restoration of Historic Buildings in Order to Test Sustainable Refurbishment: Case Study. Sustainability 2019, 11, 4009. [CrossRef]

16. ICOMOS. The Nara document on authenticity. In Proceedings of the World Heritage Convention, Nara, Japan, 1-6 November 1994; ICOMOS: Nara, Japan.

17. Martins, A.M.; Carlos, J.S. The retrofitting of the Bernardas' Convent in Lisbon. Energy Build. 2014, 68, 396-402. [CrossRef]

18. Milojković, A.; Brzaković, M.; Nikolić, M. The Influences and Importance of the UNESCO World Heritage List: The Case of Plaošnik, Ohrid. Space Cult. 2018, 23, 164-180. [CrossRef]

19. Čanak-Medić, M.; Popović, D.; Vojvodić, D. Žiča Monastery - Manastir Žiča; Institute for the Protection of Cultural Monuments of Serbia - Belgrade, Belgrade, Serbia - Republički zavod za zaštitu spomenika kulture Srbije: Beograd, Srbija, 2014.

20. Computer Program OpenStudio. 2015. Available online: https://www.openstudio.net (accessed on 20 July 2020).

21. Computer Program EnergyPlus. EnergyPlus 2018. Available online: https://energyplus.net/ (accessed on 20 July 2020).

22. Online Database: Weather Data by Region. 2018. Available online: https://energyplus.net/weather-region/ europe_wmo_region_6/SRB\%20\%20 (accessed on 20 July 2020).

23. SRPS EN ISO 6946:2017. Building Components and Building Elements-Thermal Resistance and Thermal Transmittance-Calculation Methods (ISO 6946:2017); Institute for Standardization of Serbia, Belgrade, Serbia Institut za standardizaciju Srbije: Beograd, Srbija, 2017.

24. Murgul, V. Features of energy efficient upgrade of historic buildings: Illustrated with the example of Saint-Petersburg. J. Appl. Eng. Sci. 2014, 12,1-10. [CrossRef]

25. Hensley, J.E.; Aguilar, A. Improving Energy Efficiency in Historic Buildings; Government Printing Office: Washington, DC, USA, 2012; Volume 3.

26. Turanjanin, V.; Vucicevic, B.; Jovanovic, M. Different Heating Systems for Single Family House: Energy and Economic Analysis. Therm. Sci. 2016, 20, 309-320. [CrossRef]

27. Vozikis, K.T. Protective Structures on Archaeological Sites in Greece. In Proceedings of the 2005 International Conference on Environment, Ecosystems and Development, Venice, Italy, 2-4 November 2005; Krope, W.-Z.L.J., Ed.; pp. 120-125. 